\title{
PREDATOR-PREY INTERACTIONS IN LILY BULB CROPS IN CANTERBURY
}

\author{
G.M. DRAYTON, I.A.W. SCOTT, R.F. VAN TOOR and S.R. BULMAN \\ Crop and Food Research, Private Bag 4704, Christchurch, New Zealand \\ Corresponding author: DraytonG@crop.cri.nz
}

\begin{abstract}
The presented research is part of a continuing project investigating virus transmission by aphids in export quality lily bulbs. Yellow bowl traps (YBT) were used to investigate the diversity of invertebrates within three lily bulb crops located at Rakaia, Somerton and Dorie in Mid Canterbury. YBTs were serviced weekly over a period of 20 weeks (8/11/2005 to 17/41/2006). Each site was surrounded by different crop types and therefore different potential invertebrate refugia. Invertebrate samples were sorted into six orders: Homoptera (Aphididae), Thysanoptera, Hymenoptera, Diptera, Coleoptera and Neuroptera. As predicted, invertebrate diversity differed between sites and varied over the trapping period. In general, diversity was greatest at Dorie. Predator abundance (lacewings, parasitoids) was also greatest at Dorie. Thrips were detected in large numbers during the trapping period. Thrips population cycles differed between sites in terms of both abundance and population peaks. Aphid abundance at all sites followed patterns expected from historical data with peaks in spring and late-autumn. Aphid diversity varied throughout the trapping period with peaks during spring and autumn flights. However, there was little difference between sites. Some observed variation may be due to differences in crop management practices at each site.
\end{abstract}

\section{THE DEVELOPMENT AND EMERGENCE OF PLATYGASTER DEMADES (WALKER) UNDER DIFFERENT PHOTOPERIODS AND TEMPERATURES}

\author{
X.Z. HE and Q. WANG \\ Institute of Natural Resources, Massey University, Private Bag 11222, \\ Palmerston Nth, New Zealand \\ Corresponding author: q.wang@massey.ac.nz
}

The effect of photoperiod (10:14, 11:13, 12:12, 13:11, 14:11 and 15:9 h light:dark at $20^{\circ} \mathrm{C}$ ) and temperature $\left(5,10,15,20\right.$ and $25^{\circ} \mathrm{C}$ under a photoperiod of $\left.15: 9 \mathrm{~h}\right)$ on the development and emergence of Platygaster demades (Walker), an egg-larval parasitoid of apple leafcurling midge, Dasineura mali Kieffer, was studied in the laboratory. Results show that the long photoperiod $(14: 10 \mathrm{~h})$ significantly delayed but the short photoperiod $(11: 13 \mathrm{~h})$ promoted the development and emergence of the parasitoid. Platygaster demades developed significantly faster with the increasing temperatures up to $20^{\circ} \mathrm{C}$. When the temperature reached $25^{\circ} \mathrm{C}$, most $P$. demades stopped development. Aestivation usually occurred in the egg stage. These results indicate that both photoperiod and temperature played a role in inducing aestivation in $P$. demades. Further experiments are on the way to determine critical photoperiod and temperature that induce and terminate aestivation in this parasitoid. 